\title{
Emilia Nawrotek
}

Maria Curie-Skłodowska University in Lublin, Poland

ORCID: 0000-0003-4481-6530

nawrotek.emilia@umcs.pl

\section{Protection of Biosphere Resources against Invasive Plant Species}

\author{
Ochrona zasobów biosfery przed inwazyjnymi gatunkami roślin
}

\author{
SUMMARY
}

This study addresses the assessment of the legal model of protection against invasive plant species. Invasive alien species are one of the main risks to biodiversity and related ecosystem services. The threat to biodiversity and related ecosystem services posed by invasive alien species takes various forms. Moreover, invasive alien species have a significant impact on native species and on the structure and function of the ecosystem. There is a very low awareness of this phenomenon in Poland and worldwide. Therefore, legal instruments and appropriate knowledge are the basic elements of building a strategy for dealing with invasive alien species.

Keywords: invasive plant species; alien species; invasive alien species; biodiversity

\section{INTRODUCTION}

The progressing climate change and habitat transformations as a result of increasing human activity negatively affect the preservation of biodiversity. Currently, in the era of globalisation, the intensification of international trade and tourism encourages the spread of invasive alien species, which is one of the major causes of adverse environmental changes. Some of them are colonising new areas and habitats at a relatively rapid pace, negatively affecting ecosystems. Their presence is also recorded in environmentally valuable areas which are constantly being affected by a variety of anthropogenic factors that disturb the ecological balance and allow alien elements. To prevent the progressive process of biological invasion, practical measures are increasingly being undertaken to hinder this process. The basis for these actions is the identification of threats: a detailed recognition of the 
presence and abundance of invasive species. The occurrence of an alien invasive species in a given area and its subsequent expansion causes many environmental and economic problems:

- they cause economic losses in agriculture, forestry, fishing or water management ${ }^{1}$,

- they are a source of ecological costs, the consequence of which is the need to protect and care for endangered native species, sets and ecosystems that cannot be estimated,

- they require financial resources ${ }^{2}$ to control their amounts and prevent the spread of these species ${ }^{3}$.

The fight against invasive alien species is waged using three methods: mechanical, chemical and biological. The first one is the physical removal of alien plants. The chemical method is considered controversial as the substances used adversely affect biodiversity because of their undesirable side effects. The last method consists of the introduction of a natural enemy that comes from the area of the original occurrence of the alien species concerned ${ }^{4}$.

The threat to biodiversity and related ecosystem services posed by invasive alien species takes various forms, including having a serious impact on native species and the structure and function of ecosystems through the change in habitats, forage, competition, disease transfer, replacement of native species on a significant extent of their area. The control and prevention of the release invasive alien species, including plants, into the environment is one of the newer forms of biodiversity protection ${ }^{5}$.

The protection of biodiversity ${ }^{6}$ is a modern goal of protecting nature and is, therefore, inextricably related to the concept of nature conservation. It is worth pointing to the definition formulated based on natural and legal sciences in order to properly assess the relationship between these concepts. Biodiversity is an am-

1 Estimated economic losses amount to at least 12.5 billion per year. See M. Kettunen, P. Genovesi, S. Gollasch, S. Pagad, U. Starfinger, P. Ten Brink, C. Shine, Technical support to EU strategy on invasive species (IAS) - Assessment of the impacts of IAS in Europe and the EU (final module report for the European Commission), Brussels 2008; D. Pimentel, Biological Invasions: Economic and Environmental Costs of Alien Plant, Animal, and Microbe Species, London - New York - Washington 2002.

2 For example, the cost of elimination of Prunus serotina in the Netherlands is EUR 2 million annually, and the cost of elimination of Sosnowsky's hogweed was PLN 3 million.

3 More broadly, see D. Anderwald, Gatunki obce w lasach, Rogów 2012, pp. 6-28.

4 K. Najberek, W. Solarz, Gatunki obce. Przyczyny inwazyjnych zachowań i sposoby zwalczania, „KOSMOS. Problemy Nauk Biologicznych” 2016, nr 1, pp. 85-87.

5 More broadly, see B. Jeżyńska, R. Pastuszko, Ochrona bioróżnorodności biologicznej przed uwalnianymi do środowiska obcymi gatunkami inwazyjnymi. Zagadnienie prawne, [in:] Prawne instrumenty ochrony środowiska, red. B. Jeżyńska, E. Kruk, Lublin 20166, pp. 255-256.

6 The literature indicates that the term "biodiversity" was first used by R. Dalesman in 1968 in his publication $A$ Diffrent Kind of Country, presenting the idea of nature conservation. 
biguous and complex concept ${ }^{7}$, in natural sciences it is seen as a variety of manifestations of life on Earth ${ }^{8}$. Diversity is seen at many levels of organization: genetic, species-related and ecosystem-related ${ }^{9}$. The practical approach to biodiversity is set out in the Millennium Ecosystem Assessment:

Biodiversity is the variability among living organisms from all sources, including terrestrial, marine, and other aquatic ecosystems and the ecological complexes of which they are part; this includes diversity within species, between species, and of ecosystems. In addition to the important role of biodiversity in providing ecosystem services, it also has intrinsic value, independent of any human concern ${ }^{10}$.

In the field of legal science, pursuant to the legal definition contained in the Convention on Biological Diversity adopted at the conference in Rio de Janeiro ${ }^{11}$, biological diversity means variability among living organisms from all sources including, i.a., terrestrial, marine and other aquatic ecosystems and the ecological complexes of which they are part. This applies to diversity within species, between species and ecosystems. On the other hand, nature conservation, on the basis of legal science, has the legal definitions contained in Article 2 (1) of the Polish Act of 16 April 2014 on Nature Protection ${ }^{12}$ governing the objectives, principles and forms of nature protection. According to this definition, nature protection is the conservation, sustainable use and renewal of natural resources, objects and components: wild plants, animals and fungi; plants, animals and fungi protected by species protection; animals carrying out an itinerant lifestyle; natural habitats; endangered habitats, rare and protected species of plants, animals and fungi; the objects of living and inanimate nature and fossil remains of plants and animals; landscape; greenery in towns and villages and tree stands. Thus, the primary and most important task

\footnotetext{
7 As stated by T. Swanson (Global Action for Biodiversity, London 1997, p. 5), biodiversity refers to the natural stock of genetic material within an ecosystem, conditioned by the current amount of genes present in this ecosystem. A similar definition was formulated by A. Liro, M. Metler, W. Nowicki and A. Weigle (Krajowa strategia i plan działań na rzecz ochrony i racjonalnego użytkowania różnorodności biologicznej, Warszawa 1998, p. 1), who stated that "biological diversity means genetic variability (the richness of the gene pool) of each living population, as well as the composition of species and diversity of ecological systems occurring on Earth". An even more precise definition was proposed by E.O. Wilson (The current state of biological diversity, [in:] Biodiversity, eds. E.O. Wilson, F.M. Peter, Washington 1988, s. 3-18), according to whom biodiversity is "genetic based variation of living organisms at all levels, from the variety of genes in populations of single species, through species, on up to the array of natural ecosystems", as well as the diversity of ecosystems - both organisms living in specific habitats and the physical conditions in which they live.

8 M.J. Jefferies, Biodiversity and Conservation, New York 2006, p. 5.

9 M. Hunter, Fundamentals of Conservation Biology, Oxford 2002, p. 19.

10 Millennium Ecosystem Assessment, Washington 2005, p. 7.

11 Convention on Biological Diversity, Rio de Janeiro, 5 June 1992 (United Nations, Treaty Series, Vol. 1760, p. 79).

12 Consolidated text Journal of Laws 2017, item 1074, hereinafter: ANP.
} 
of nature protection is to care for the conservation and sustainable use of natural resources $^{13}$. This is a manifestation of the so-called conservative protection of the natural environment, which consists in protecting certain elements or environmental values from destruction or degradation, for ecological reasons ${ }^{14}$.

The issue of alien invasive species released into the environment as a result of the growth of world trade, transport, tourism is becoming increasingly significant, and signatories to the Convention are, therefore, required to prevent, as much as possible, the introduction, control or eradicating of alien species that threaten ecosystems, habitats or species, through a wide range of legal and organizational instruments.

\section{THE NOTIONS OF ALIEN SPECIES AND INVASIVE ALIEN SPECIES}

Biological invasions of alien species are one of the most complex problems in nature protection. The difficulty is the very definition of the concept of an alien species, and this solution is not facilitated by varied terminology, because interchangeably and inconsistently alien species are referred to as introduced, exotic, acclimatized ones. Such terminological inconsistency translates primarily into the difficulty with creating legal solutions aimed at preventing biological invasions and mitigating their effects ${ }^{15}$.

The Conference of the Parties of the Convention on Biological Diversity (COP) adopted Decision VI/23 on Alien species that threaten ecosystems, habitats or species, the Annex of which sets out the basic principles for preventing, introducing and mitigating the impact of such alien species. This document defines the basic concept of biological invasion. An alien species is a species, subspecies or lower taxon, introduced outside its natural past or present distribution; including any part, gametes, seeds, eggs, or propagules of such species that might survive and subsequently reproduce. And invasive alien species are defined as those means an alien species whose introduction and/or spread threaten biological diversity and related ecosystem services, or affects them in an undesirable way. Another important term is "introduction", i.e. movement by human agency, indirect or direct, of an alien species outside of its natural range. The movement can be either within a country or between countries or areas beyond national jurisdiction.

Then the definitions of alien species and alien invasive species were included in the provision of Article 3 of Regulation (EU) No. 1143/2014 of the European

${ }^{13}$ K. Gruszecki, Ustawa o ochronie przyrody, Komentarz, LEX/el. 2010.

14 R. Paczuski, Prawo ochrony środowiska, Bydgoszcz 2000, p. 438.

15 W. Solarz, Przyczyny i skutki inwazji biologicznych na świecie i w Polsce, „Studia i Materiały CEPL w Rogowie" 2012, z. 33(4), pp. 10-11. 
Parliament and of the Council of 22 October 2014 on the prevention and management of the introduction and spread of invasive alien species ${ }^{16}$ and states that alien species means any live specimen of a species, subspecies or lower taxon of animals, plants, fungi or micro-organisms introduced outside its natural range; it includes any part, gametes, seeds, eggs or propagules of such species, as well as any hybrids, varieties or breeds that might survive and subsequently reproduce; while invasive alien species means an alien species whose introduction or spread has been found to threaten or adversely impact upon biodiversity and related ecosystem services.

Under Polish national law, the notion of alien species was normatively defined and is included in the statutory glossary in the Act on Nature Protection (Article 5 (1c) ANP) as a species occurring outside its natural range in the form of individuals or survivable gametes, spores, seeds, eggs or parts of individuals using which they can reproduce.

The notion of foreign species is quite vague. It can be understood ambiguously. In a broad sense, it will cover all species of plants, animals and fungi, which originally had not occurred in the national natural environment, but were introduced into it and even acclimatized throughout history. In a narrower sense, alien species should be understood as those species that do not yet occur in this environment. The literature on the subject emphasizes that the concept of alien species should be understood in a broad sense, because the narrow approach is not precise ${ }^{17}$.

\section{PROTECTION AGAINST INVASIVE SPECIES IN INTERNATIONAL LAW}

Although the issues of preventing uncontrolled transfer and introduction of species were addressed for the first time in the Convention on the Conservation of European Wildlife and Natural Habitats of 19 September $1979^{18}$, but the act of international law of fundamental importance in this regard is the Convention on Biological Diversity. In accordance with its Article 8, the Parties agreed to take steps to prevent the introduction, to control or erase alien species which threaten ecosystems, habitats or individual species. The adopted model of protection has become a starting point for the establishment of an EU solution for the biological invasion of alien species, resulting in the adoption of the aforementioned Regulation (EU) No. 1143/2014 of the European Parliament and of the Council of 22 October 2014 on the prevention and management of the introduction and spread of invasive alien species. Regulation 1143/2014 is a fundamental source of law on the prevention of adverse effects on biological diversity of the deliberate and unintended introduction and

\footnotetext{
16 OJ L 317/35, 4.11.2014.

17 K. Gruszecki, op. cit.

18 Journal of Laws 1996, No. 58, item 263; OJ L 38/3, 10.02.1982.
} 
spread of invasive alien species and on minimising and mitigation of these effects. The Regulation introduces a prohibition of intentional action in the form of bringing into the territory of the Union, including by transit under customs supervision; storage, including in contained holding; breeding, including in contained holding; transporting to, from or within the Union, except for the transportation of species to facilities in the context of eradication; placing on the market; use or exchange; permitting to reproduce, grown or cultivated, including in contained holding; or release into the environment. However, the restrictive EU model of protection of native species is significantly undermined by the provision contained in Article 8 of Regulation 1143/2014. By way of exception from restrictions, Member States establish an authorization system enabling research centres to carry out scientific research or ex situ protection regarding invasive alien species posing a threat to the Union. Where the use of products derived from invasive alien species posing a threat to the Union is unavoidable due to progress in the field of human health, Member States may also include production for scientific purposes and subsequent medical use in their authorization schemes.

The protection of native ecosystems against invasive species has not been fully regulated in Regulation 1143/2014, since pursuant to the preamble, the Member States have been granted the possibility of retaining or adopting provisions on invasive alien species posing a threat to the Union which are more stringent than those laid down in this Regulation. This means the power of a Member State to introduce into its national legal order legal institutions involving a prohibition of the introduction of invasive alien species posing a threat to ecosystems into the environment.

\section{PROTECTION AGAINST INVASIVE SPECIES IN NATIONAL LAW}

The legal protection of the environment against alien species has been defined in the Act of 16 April 2004 on the Protection of Nature. The provision of Article 120 ANP introduces a general prohibition of introducing plants, animals or fungi of alien species and other organism forms into the natural environment and on the movement of plants, animals or fungi in this environment. More detailed regulation concerning invasive species is included in the Regulation of the Minister of the Environment of 9 September 2011 on the List of Plants and Animals of Alien Species which, if released into the natural environment, may pose a threat to native species or habitats ${ }^{19}$.

Another legal instrument to protect the natural environment against penetration of alien species is the obligation under Article 120 (2) ANP to obtain a permit to

${ }^{19}$ Consolidated text Journal of Laws 2011, No. 210, item 1260. 
import plant, animal or fungi species whose introduction into the environment may pose a threat to native species, and to keep, breed, reproduce, offer for sale and dispose of these species.

As regards the permission for the introduction of alien species, it is necessary to identify in which cases it will be required at all. It follows from the provisions of Article 120 (2) ANP that one of such conditions is the possibility of posing a threat to native species. This threat should be understood very broadly and not necessarily result directly from the characteristics of a particular species.

The provision of Article 120 (2d) (1) ANP sets out an absolute condition for issuing the permit if the applicant has been convicted by a final court judgement for an offence related to cross-border transporting, keeping, breeding, propagating and selling plants, animals or fungi of alien species on the territory of Poland within 3 years from the date of the final judgement. On the other hand, Article 120 (2d) (2) ANP provides for a relative condition for issuing the permission in question, as the provision stipulates that the competent authority may refuse to issue the permit if the activity applied for poses a threat to native species or natural habitats.

Also noteworthy is the weakening of the restrictive model of protection of native species against biological invasion, as an exception to the general rule, i.e. prohibiting any introduction and movement of alien species into/within the environment. Plants introduced and moved in connection with the establishment and maintenance of green areas and maintenance of tree stands outside forests and areas covered by forms of nature protection were excluded from this rule (Article 120 (4) (1) ANP) and the introduction and movement of alien plant species within the rational fores $\mathrm{t}^{20}$ and agricultural management was allowed (Article 120 (4) (1) $\mathrm{ANP})^{21}$. In practice, this exception also has a very broad scope. Moreover, when listing the exceptions from the scope of introduction and movement of alien plant species specified in Article 120 (4) ANP, we will notice that in practice the prohibition of introduction of alien plant species is only applicable in the areas covered

20 According to J. Pakuła (Pojęcie i zasady gospodarki leśnej, [in:] Wybrane problemy prawa leśnego, red. B. Rakoczy, Warszawa 2011, pp. 86-87), rational forest management is one that uses modern scientific methods, and employs planning instruments that make it possible to achieve good results. Therefore, rational forest management is generally considered in purely economic terms, focused on the financial effect (in the form of production potential or economic result of the production unit). For more, see D. Danecka, A. Habuda, W. Radecki, J. Rotko, Polskie prawo leśne, Warszawa 2016, p. 167.

${ }^{21}$ The term "rational agricultural management" has not been normatively defined. The issues of rational agricultural management was discussed in more detail in: M.A. Król, Racjonalna gospodarka rolna na obszarach objętych prawnymi formami ochrony przyrody, „Studia Iuridica Agraria” 2012, t. 9, pp. 306-327; eadem, Prawna ochrona bioróżnorodności $w$ działalności prowadzonej na terenach objętych jedna z obszarowych form ochrony przyrody, [in:] Prawo ochrony przyrody a wolność gospodarcza, red. M. Górski, Łódź-Poznan 2011. 
by forms of nature protection specified in the Act. Therefore, the exception has turned into a rule, contrary to the purpose of the institution ${ }^{22}$.

\section{CONCLUSIONS}

Threats to biodiversity and related ecosystem services posed by invasive alien species take many forms, including exerting a serious impact on native species as well as their structure and function. Furthermore, invasive alien species may also have a significant adverse effect on human health and the economy. Threats to biodiversity and related ecosystem services, human health and the economy, posed invasive plant species, are subject to restrictions under legal instruments adopted.

Biological invasions can be widespread and nationwide, usually when alien invasive species are introduced extensively and repeatedly, or local, if they are grown in many places, usually without satisfactory economic results. The issue of invasion and invasive plants has been the subject of great interest of both botanists ${ }^{23}$ and lawyers dealing with nature protection in recent years. Biological invasions rarely occur in stable and natural ecosystems, therefore one of the basic principles of effective invasion prevention should be care for the condition of the natural environment and education, due to low awareness of this phenomenon which hinders the effective mitigation of the effects in native biodiversity. The problem of invasive plant species is a complex one. Thus, legal instruments and appropriate knowledge are the basic elements of building a strategy for dealing with invasive alien species ${ }^{24}$.

The Polish national legal model for the protection of native species of wildlife deserves a positive assessment, but still some solutions raise reservations: firstly, the regulations containing exceptions to general rules, because all exceptions to the rules should be very precise and should not raise any doubts as to the scope of their validity, therefore this exception (Article 120 (4) (1) and (2) ANP) should be restricted because it may constitute a source of serious threats to native biological diversity, and secondly, the discretion of the competent authority adjudicating on the issuance of the permission may be doubtful (Article 120 (2d) (2) ANP).

${ }^{22}$ K. Gruszecki, op. cit.

${ }^{23}$ More broadly, see W. Danielewicz, B. Wiatrowska, Inwazyjne gatunki drzew i krzewów w lasach Polski, „PECKIANA” 2014, No. 9, pp. 59-67; H. Okarma, W. Solarz, Inwazje biologiczne - niedoceniony problem w ochronie przyrody, „Wszechświat 110” 2009, nr 10-12, pp. 14-20; A. Bomanowska, I. Kirpluk, W. Adamowski, J. Palus, A. Otręba, Problem inwazji roślin obcego pochodzenia w polskich parkach narodowych, [in:] Inwazyjne gatunki roślin w Kampinoskim Parku Narodowym i jego sąsiedztwie, red. A. Otręba, D. Michalska-Hejduk, Izabelin 2014, pp. 9-14.

${ }^{24}$ W. Solarz, H. Okarma, Rekomendacje, [in:] Gatunki obce w faunie Polski, red. Z. Głowaciński, H. Okarma, J. Pawłowski, W. Solarz, Kraków 2011, pp. 512-520. 


\section{REFERENCES}

\section{Literature}

Anderwald D., Gatunki obce w lasach, Rogów 2012.

Bomanowska A., Kirpluk I., Adamowski W., Palus J., Otręba J., Problem inwazji roślin obcego pochodzenia w polskich parkach narodowych, [in:] Inwazyjne gatunki roślin w Kampinoskim Parku Narodowym i jego sasiedztwie, red. A. Otręba, D. Michalska-Hejduk, Izabelin 2014.

Danecka D., Habuda A., Radecki W., Rotko J., Polskie prawo leśne, Warszawa 2016.

Danielewicz W., Wiatrowska B., Inwazyjne gatunki drzew i krzewów w lasach Polski, „PECKIANA” 2014, No. 9.

Gruszecki K., Ustawa o ochronie przyrody, Komentarz, LEX/el. 2010.

Hunter M., Fundamentals of Conservation Biology, Oxford 2002.

Jefferies M.J., Biodiversity and Conservation, New York 2006.

Jeżyńska B., Pastuszko R., Ochrona bioróżnorodności biologicznej przed uwalnianymi do środowiska obcymi gatunkami inwazyjnymi. Zagadnienie prawne, [in:] Prawne instrumenty ochrony środowiska, red. B. Jeżyńska, E. Kruk, Lublin 2016.

Kettunen M., Genovesi P., Gollasch S., Pagad S., Starfinger U., Ten Brink P., Shine C., Technical support to EU strategy on invasive species (IAS) - Assessment of the impacts of IAS in Europe and the EU (final module report for the European Commission), Brussels 2008.

Król M.A., Prawna ochrona bioróżnorodności w działalności prowadzonej na terenach objętych jedna z obszarowych form ochrony przyrody, [in:] Prawo ochrony przyrody a wolność gospodarcza, red. M. Górski, Łódź-Poznań 2011.

Król M.A., Racjonalna gospodarka rolna na obszarach objętych prawnymi formami ochrony przyrody, „Studia Iuridica Agraria” 2012, t. 9.

Liro A., Metler M., Nowicki W., Weigle A., Krajowa strategia i plan dziatań na rzecz ochrony i racjonalnego użytkowania różnorodności biologicznej, Warszawa 1998.

Millennium Ecosystem Assessment, Washington 2005.

Najberek K., Solarz W., Gatunki obce. Przyczyny inwazyjnych zachowań i sposoby zwalczania, „KOSMOS. Problemy Nauk Biologicznych” 2016, nr 1.

Okarma H., Solarz W., Inwazje biologiczne - niedoceniony problem w ochronie przyrody, „Wszechświat 110" 2009, nr 10-12.

Paczuski R., Prawo ochrony środowiska, Bydgoszcz 2000.

Pakuła J., Pojęcie i zasady gospodarki leśnej, [in:] Wybrane problemy prawa leśnego, red. B. Rakoczy, Warszawa 2011.

Pimentel D., Biological Invasions: Economic and Environmental Costs of Alien Plant, Animal, and Microbe Species, London - New York - Washington 2002.

Solarz W., Przyczyny i skutki inwazji biologicznych na świecie $i$ w Polsce, „Studia i Materiały CEPL w Rogowie" 2012, z. 33(4).

Solarz W., Okarma H., Rekomendacje, [in:] Gatunki obce w faunie Polski, red. Z. Głowaciński, H. Okarma, J. Pawłowski, W. Solarz, Kraków 2011.

Swanson T., Global Action for Biodiversity, London 1997.

Wilson E.O., The current state of biological diversity, [in]: Biodiversity, eds. E.O. Wilson, F.M. Peter, Washington 1988. 
Pobrane z czasopisma Studia Iuridica Lublinensia http://studiaiuridica.umes.pl Data: 26/04/2023 13:55:57

\section{Legal acts}

Act of 16 April 2014 on Nature Protection (consolidated text Journal of Laws 2017, item 1074).

Convention on the Conservation of European Wildlife and Natural Habitats of 19 September 1979 (Journal of Laws 1996, No. 58, item 263; OJ L 38/3, 10.02.1982).

Convention on Biological Diversity, Rio de Janeiro, 5 June 1992 (United Nations, Treaty Series, Vol. 1760, p. 79).

Regulation (EU) No. 1143/2014 of the European Parliament and of the Council of 22 October 2014 on the prevention and management of the introduction and spread of invasive alien species (OJ L 317/35, 4.11.2014).

Regulation of the Minister of the Environment of 9 September 2011 on the list of Plants and Animals of Alien Species (consolidated text Journal of Laws 2011, No. 210, item 1260).

\section{STRESZCZENIE}

Niniejsze opracowanie dotyczy oceny modelu prawnej ochrony przed inwazyjnymi gatunkami roślin. Inwazyjne gatunki obce stanowią jedno z głównych zagrożeń dla różnorodności biologicznej i powiązanych usług ekosystemowych. Zagrożenie dla bioróżnorodności i powiązanych usług ekosystemowych, jakie stwarzają inwazyjne gatunki obce, przybiera różne formy. Ponadto inwazyjne gatunki obce wywierają znaczny wpływ na gatunki rodzime oraz strukturę i funkcję ekosystemów. W Polsce i na świecie jest bardzo niska świadomość o tym zjawisku. Stąd też instrumenty prawne i odpowiednia wiedza są podstawowymi elementami budowania strategii postępowania z inwazyjnymi gatunkami obcymi.

Słowa kluczowe: inwazyjne gatunki roślin; gatunki obce; inwazyjne gatunki obce; bioróżnorodność 